\title{
The Influence of Psikoedukasi on Stress Management in Improving Self Efficacy and Coping Mechanism of Families in Caring for Caring for ODGJ Patient (Schizophrenia) at Public Health Center of Balowerti Kediri Regency
}

\author{
Eka Lutfiatus Solehah ${ }^{1}$, Byba Melda Suhita ${ }^{2}$, Yuly Peristiowati ${ }^{2}$ \\ ${ }^{1}$ Magister of Health Study Program, STIKes Surya Mitra Husada Kediri \\ ${ }^{2}$ Lecturer of STIKes Surya Mitra Husada Kediri \\ Email: ekasoleha2018@gmail.com
}

\begin{abstract}
Received 21 February 2019; Accepted 21 February 2019; Published 22 May 2019
\end{abstract}
\begin{abstract}
Families need to have the attitude of accepting patients, give a positive response, appreciate the patient as family members and foster an attitude of responsibility to the patient, so the balance of life in the family may occur. The existence of the soul in the family of disorders affecting the function of the family. Families that work well will be able to provide care on a family member with good and vice versa. Research objectives to analyzed the influence of psikoedukasi on stress management in improving self efficacy and mechanism of ODGJ in caring for families koping (Schizophrenia). Design research is to take the pretest-posttest alphabets experiment pre design. The research of the variable Psikoedukasi as the independent variable and self efficacy and mechanism of the dependent variables as koping. The population of the study were al of ODGJ patient Public Health Center of Balowerti Kediri Regency by as much as 46 patients. Samples taken by random sampling technique as much as 41 respondents. Data collected by questionnaire instrument and processed by using coding, editing, tabulating and scoring as well as tested with paired $t$ test statistics. Paired $t$ test test results showed a psycho educational influence on self efficacy and mechanism of koping family in taking care of patients with schizophrenia in Kediri Regency Balowerti Clinics, indicated by the value of the second variable significance are $0.000<0.05$ so that $\mathrm{H} 1$ is accepted means there is the influence of the psycho education towards self efficacy and mechanism of koping in families with schizophrenia in Public Health Center of Balowerti Kediri Regency. Granting psikoedukasi of stress management can assist families in determining the right strategy koping to adapt to that form, where families can adapt well to situations that occur when caring for schizophrenia patients.
\end{abstract}

Keywords: Psikoeducation, self efficacy, koping mechanism, family, skizofrenia

Copyright $($ ) 2019 STIKes Surya Mitra Husada

All right reserved.

This is an open-acces article distributed under the terms of the Creative Commons AttributionShareAlike 4.0 International License.

\section{INTRODUCTION}

Mental health is still a serious problem in Indonesia and these problems are likely to continue to increase, so that the necessary action and countermeasures of comprehensive and continuous. Philosophy, mission and characteristics of mental health nursing Service refers to the paradigm of 
nursing about phenomenal Central the man, the environment, health and nursing for mental health nursing can provide a holistic, comprehensive and continuous improvement. Mental health is part of overall health, not just free from the distractions of the soul, but the fulfillment of needs a feeling of happy, healthy, and able to handle life's challenges. Medically, mental health was translated as a condition that allows the development of physical, intellectual, and emotional are optimal from a person. The development goes in harmony with the circumstances of others (Febriani, 2008 within the Son, 2015).

Disorder of schizophrenia is a chronic mental disorder where the sufferer often have relapse ${ }^{\text {ee }}$ or "relaps. According to what (2000), sufferers have ideas that are illogical, erroneous perceptions, a chaotic motor activity, emotions that are not reasonable or blunt, withdrew from the interpersonalnya relation, as well as having his own so sufferers lose contact with reality and his life is not in accordance with the demands of real life in the community. Signs of such behaviour is often referred to by the layman as "crazy " or people are not sane ". The stigma that keeps the majority of the community think that the sufferer "dangerous " and may threaten the safety of the people around them, so it appears the treatment-discrimination to them, such as exclusion, not given the role at home, given the violence, etc. (Wijaya, 2014).

Discriminatory treatment given to sufferers of the disease also affects the sufferer's recovery process. The recovery process in Indonesia apat schizophrenic is said to be still worse. The handling process take a long time and is long, ranging from care at hospitals, dispensing, to social support from family and society (Taufik, 2013). Handling is multifaktor, meaning that any handling of the intertwined and can not walk respectively. For example, a patient who already get the medication properly, get a good treatment process in hospital, but if you don't get support from your family and the environment then the patient could be back relaps. Therefore, for the recovery of the patient's condition is not only necessary but also drugs needed support from family or the environment (Originally,2014).

According to the World Health Organization (WHO) (2016), Indonesia was ranked the 4th largest population in the world. And sufferers of the disorder in Iondonesia which is about 26 million people, ranging from mild to severe psychiatric. Sufferers of the disorder in Java increase drastically in the year 2016. Ironically, most sufferers are those who are productive. Based on data from Dinsos Jatim, sufferers of the disorder in East Java in the year 2016 reached 2,369 people. That number rose by 750 people than in 2015 and then that only 1,619 people sufferers. Preliminary results of a study conducted in the region of clinics Balowerti Kediri against 6 ODGJ with the patient's family obtained the data 4 families feel burdened and embarrassed in the care of family members who have experienced psychiatric, while 2 families receive their natural circumstances of the moment and let go with what happened. In the implementation of educational programs of patient care ODGJ still not there are families who receive education with good enough about ODGJ care.

Keliat (2011) identified the cause of the recurrence factor is knowledge, attitudes, and actions of the family in caring for psychiatric patients. Families need to have the attitude of accepting patients, give a positive response, appreciate the patient as family members and foster an attitude of responsibility to the patient, so the balance of life in the family may occur. The existence of the soul in the family of disorders affecting the function of the family. Families that work well will be able to provide care on a family member with good and vice versa. Besides the confidence families (Self Efficay) will make the family capable of performing maintenance on paisen ODGJ well. Self efficacy is a strong predictor for change as well as to maintain behavior, if self efficacy are good, then the family had the ability to take care of anyway. Common constraints faced by the families of schizophrenic is the difficulty of access to mental care, medical costs are expensive, and the lack of dissemination of basic information (Taufik, 2013). The cost of the care and treatment that is costly already trying the Government attempted with the giving of the treatment free of charge. However, the constraints of the lack of basic information about a mental disorder itself still haven't gotten serious attention when in fact this information is very important to help families understand the sufferer of schizophrenia disorder suffered by asien. The granting of such basic information is called psikoedukasi (the Wijaya, 2014).

Undeniable family crisis and will also be undergoing pressure when noticed that one member of his family suffer from disorders of the soul. This pressure will be a source of stress for the paraanggota in the family. Meanwhile, for families who are vulnerable to stress, surely it will interfere 
with their role as system support that resulted in the more stable disorders sufferers not a soul in the healing process (Kristyanti \& Rosalina, 2009). To cope with stress, then the family has a specific way to lose stressor and regulate the situation in addressing the stressor is known by the term mechanism koping (son, 2015). One effort that can be done to reduce the stress experienced by families in the care of patients with disorders of the soul among others with family stress management psikoedukasi therapy in patients with disorders of the soul.

Psikoedukasi family is the giving of information or knowledge on the family about the disease suffered by family members with the aim to reduce the tendency to relapse and reduce the influence of the ailment in the Member the other family (Townsend,2009). In the application psikoedukasi much given to patients with psychiatric disorders including family members and the interested parties to take care of these patients (Lukens \& Mcfarlane, 2004). Based on the evidancebased psikoedukasi family practice is a therapy that is used to provide information on the family to improve their skills in taking care of their family members who have experienced psychiatric, so expect the family will have a positive koping against stress and load hers. Other opinion explains that the psikoedukasi family is the grant education to someone that supports treatment and rehabilitation (Goldenberg, 2004).

Based on the explanation on the background above, researchers interested in conducting research with the title the influence of psikoedukasi on stress management in improving self efficacy and mechanism of ODGJ in caring for families koping (Schizophrenia).

\section{MATERIALS AND METHODS}

Design research is to take the pretest-posttest alphabets experiment pre design. The research of the variable Psikoedukasi as the independent variable and self efficacy and mechanism of the dependent variables as koping. The population of the study were al of ODGJ patient Public Health Center of Balowerti Kediri Regency by as much as 46 patients. Samples taken by random sampling technique as much as 41 respondents. Data collected by questionnaire instrument and processed by using coding, editing, tabulating and scoring as well as tested with paired $t$ test statistics.

Data analysis in this research are as follows:

\section{Self Efficay Value}

Measurement of self efficacy using with alternative answers using the Likert scale. As for the assessment are given as follows:

\begin{tabular}{llll}
\hline & Favorabel & & Unfavorable \\
\hline Very Sure & $: 4$ & Very Sure & $: 1$ \\
Sure & $: 3$ & Sure & $: 2$ \\
Enough Sure & $: 2$ & Enough Sure & $: 3$ \\
Not Sure & $: 1$ & Not Sure & $: 4$ \\
\hline
\end{tabular}

2) Penilaian Mekanisme Koping

The measurement mechanism koping using assessment as follows:

\begin{tabular}{llll}
\hline & Favorabel & & Unfavorable \\
\hline Very Agree & $: 4$ & Very Agree & $: 1$ \\
Agree & $: 3$ & Agree & $: 2$ \\
Disagree & $: 2$ & Disagree & $: 3$ \\
Very Disagree & $: 1$ & Very Disagree & $: 4$ \\
\hline
\end{tabular}




\section{RESULTS}

\section{Analisis Data With Paired T Test}

Table 4.1 The results of the analysis of the Paired T test the influence of Psycho Education towards Self Efficacy and mechanism of koping family with skizofrenia patient in Public Health Center of Balowerti Kediri Regency in October $2018(n=41)$

\begin{tabular}{lccccc}
\hline \multirow{2}{*}{ Group } & \multirow{2}{*}{ Mean } & \multirow{2}{*}{ SD } & \multirow{2}{*}{ P value } & \multicolumn{2}{c}{ CI 95\% } \\
\cline { 5 - 6 } & & & & Lower & Upper \\
\hline Efikasi Pre dan Postest & 0,488 & 0,506 & 0,000 & 0,648 & 0,328 \\
\hline $\begin{array}{l}\text { Coping mechanism pre dan } \\
\text { postest }\end{array}$ & 0,512 & 0,506 & 0,000 & 0,672 & 0,352 \\
\hline
\end{tabular}

Based on the results in table 4.1 shows that paired t test test results showed a psycho educational influence on self efficacy and mechanism of koping family in taking care of patients with schizophrenia in the Kediri Regency Balowerti Clinics indicated by the value of the second variable significance 0.05 i.e. $0.000<$ so that $\mathrm{H} 1$ is accepted means there is the influence of the psycho education towards Self Efficacy and mechanism of koping family with skizofrenia patient in Public Health Center of Balowerti Kediri Regency.

\section{Multivariat Analysis}

1) Partially Analysis

Tabel 4.2 Logistic Regretion by partially analysis of influence Psycho Education towards Self Efficacy and mechanism of koping family in Public Health Center of Balowerti Kediri Regency in October $2018(n=41)$

\begin{tabular}{ccccccc}
\hline Group & B & S.E & Wald & df & Sig & EXp (B) \\
\hline Efikasi & 1.892 & .566 & 11.154 & 1 & .001 & 6.630 \\
\hline Mekanisme Koping & 2.105 & .580 & 13.186 & 1 & .000 & 8.209 \\
\hline
\end{tabular}

Based on the results in table 4.2 shows that psycho education affect both partially variable of self efficacy and mechanism of koping where indicated by the value of the wald on self efficacy of 11,154 with 0.001 and significance on the mechanism koping value wald of 13,186 with significance of 0.000 . The results of this research show that partially or alone - own psikoedukasi can affect each variable because the value significance $<0.05$.

\section{2) Simultaneously Analysis}

Tabel 4.3 Logistic Regretion by simultaneously analysis of influence Psycho Education towards Self Efficacy and mechanism of koping family in Public Health Center of Balowerti Kediri Regency in October $2018(n=41)$

\begin{tabular}{ccccc}
\hline & \multicolumn{4}{c}{ Classification Table } \\
\cline { 2 - 4 } & \multicolumn{3}{c}{ Kelompok } & \multirow{2}{*}{ Percentage Correct } \\
\cline { 2 - 4 } & & Pretest & Postest & \\
\hline \multirow{2}{*}{ Kelompok } & Pretest & 36 & 5 & 87.8 \\
\cline { 2 - 4 } & Postest & 14 & 27 & 65.9 \\
\hline Overall Percentage & & & 76.8 \\
\hline
\end{tabular}

Based on the results in table 4.3 indicates that psycho education affects simultaneously both the variable self efficacy and mechanism of koping where indicated by the value of the overall 
percentage of 76.8 meaning that psikoedukasi can affect the second variable of $76.8 \%$. The results of this research show that simultaneously or simulta psikoedukasi can affect both variables self efficacy and mechanism of koping.

\section{DISCUSSION}

\section{A. Identify self efficacy in treating family ODGJ (Schizophrenia) in Public Health Center of Balowerti Kediri Regency}

Based on the results of research on self efficacy suggests that before the given psikoedukasi on schizophrenic family mostly have low self efficacy in treating sufferers as much as 29 respondents $(70.7 \%)$ and after given the majority of psikoedukasi have high self efficacy as much as 32 respondents (78\%). The results of this research show that the awarding of the psikoedukasi family in taking care of patients of schizophrenia affects self efficacy families become better than prior to the given psikoedukasi.

Results of Lyanovitasari research (2017) supportive group therapy influence the title against load and koping mechanism of the family in caring for patients data research results obtained by schizophrenia there is a difference between the load and the mechanism before the koping supportive therapy and after treatment ( $\mathrm{p}$ value $=0.000$ ). There is a difference between the control group load before and after health education ( $\mathrm{p}$ value $=0,010$ ), but there is no difference between the koping mechanisms before and after health education ( $\mathrm{p}$ value $=0,225)$. There is a significant difference on the load $(\mathrm{p}$ value $=0.002)$ and koping mechanism $(\mathrm{p}$ value $=0.001)$ between the intervention and control groups after the given supportive therapy. The PROVINCIAL HOSPITAL Dr. Rehatta is expected to facilitate the establishment of the existence of a peer support group in the family at the poli family mental health so that the soul can be achieved.

Physiological State and Emotional Arousal (a State of physiological and psychological), namely the emotional condition of stressful situations. Emotional turmoil, a profound unease, and a weak physiological circumstances experienced by individuals will be perceived as a cue will occur unwanted events. Anxiety and stress that occurs in a person while performing a task is often interpreted as a failure. In General, a person will tend to expect success in conditions that are not colored by tension and not feel any complaints or other somatic disorders. Therefore, self efficacy are usually characterized by low levels of stress and anxiety. In contrast, low self efficacy was marked by anxiety and stress level higher (Bandura, in Yayan, 2013).

The results showed that before the given psycho education many families who experience low self efficacy because the family felt burdened in caring for their family members who experience schizophrenia disorder or disturbance of jiawa. The existence of a less family-owned knowledge in treating patients with schizophrenia cause families to feel heavy and uncomfortable in the perawtan menjalanakan, let alone supported the existence of the stigma of the society towards patients with disorders of the soul becomes a burden for the family. Besides it also needs care and daily necessities that may sometimes be difficult to be filled due to the process of care of patients with disorders of the soul takes time which is not for a bit.

Based on the table regarding the relationship between self efficacy before given psycho therapy stress management education regarding the characteristics of respondents obtained data from 26 respondents aged 36-45 years mostly have low self efficacy as many as 17 respondents $(65.4 \%)$ and on respondents aged 26-35 years half of it has low self efficacy and half of them also have high self efficacy. Based on table 4.6 describes the relationship between self efficacy after the therapy given psycho education regarding stress management with characteristics of respondents obtained data from 26 respondents aged 36-45 years mostly have a self high efficacy as much as 21 respondents $(80.8 \%)$ and on 2 respondents aged 26-35 years entirely to have a high self efficacy.

According to research Yayan (2013) States one of the factors that influence self efficacy is age. Self efficacy is formed through a process of social learning that can take place during their life. Older individuals tend to have a span of time and more experience in overcoming a thing that happened when compared to younger individuals, who may still have little experience and the events in his life. Older individuals will be better able to overcome the obstacles in his life compared to younger individuals, it also deals with the experience of individuals have throughout the span of his life.Hasil 
penelitian in menunjukkan bahwasaanya usia responden termasuk usia dewasa akhir dimana dengan usia tersebut responden akan lebih mudah untuk memahami informasi yang diterima terutama tetna pendidikan kesehatan yang diberikan oleh petugas tentang perawatan pada pasien skizofrenia dan bagaimana memanajemen stress yang dihadapi oleh care giver sehingga banyak care giver yang sebelum memiliki self efficacy rendah sebelum diberikan psiko edukasi menjadi self efficacy tinggi.

Based on educational care giver before the given psikoedukasi obtained the data from the 3 respondent that a graduate SCHOOL, most have low efficacy sefl 2 respondents. On the respondents mostly SLTA graduates also have low self efficacy as much as 21 respondents (70\%). On respondents that most college graduates had low self efficacy as 6 respondents $(75 \%)$. Educational care giver based on having rendered psikoedukasi data obtained from 3 of the respondents who are graduates of the JSS entirely has high efficacy sefl. On the respondents mostly SLTA graduates also have high self efficacy as much as 24 respondents $(80 \%)$. On respondents that most college graduates have high self efficacy as much as 5 respondents $(52.5 \%)$.

BANDURA describes a person with high self efficacy they were able to approach the difficult task as a challenge that must be mastered rather than as a threat that a person with high self efficacy believe they are able to do something for changing the surrounding events, whereas a person with low self efficacy considers itself essentially incapable of working on something that exists around them. In the difficult situation of the people with low self efficacy tend to be easy to give up. While a person with high self efficacy would try harder to overcome challenges that exist. In general people will act to achieve the goal, the result of this research showed respondents educational background is secondary education so that they are reasonably able to understand and explain how to create a stress faced when doing treatments on patients of schizophrenia so many respondents who had a high after being given effcicy self psikoedukasi about stress management in caring for sufferers of skixofrenia (Shohifatul, 2012).

\section{B. Identify the mechanisms ODGJ in caring for families koping (Schizophrenia) in Public Health Center of Balowerti Kediri Regency}

Based on the results of research on the mechanism of koping pointed out that before the given psikoedukasi family on schizophrenic the majority has the mechanism of Adaptive Mall koping in treating sufferers as much as 28 respondents $(68.3 \%)$ and After most of the psikoedukasi have given the mechanism of Adaptive koping by as much as 34 respondents $(82.9 \%)$. The results of this research show that the awarding of the psikoedukasi family in taking care of patients of schizophrenia affecting mechanism koping families become better than prior to the given psikoedukasi.

Koping mechanism is carried out by individuals in menyelesaiakan the problem, adjusting to changes, response to situations that threaten. The efforts of these individuals can be cognitive, behavior change and environmental change that aims to resolve the stress encountered. The ability of humans to afford necessary koping survive in its environment-changing swiftly. Koping is problem solving in which someone uses it to manage stress conditions. With the causes of stress/stressor then people will consciously and unconsciously to react to fix the issue. Nursing concepts in koping very necessary because all patients experiencing stress, so very necessary ability to cope and the ability of the koping for adaptation to the stress which is the most important determining factor in the welfare of human (Keliat, 2011).

Koping mechanism that occurs in families who care for family members with schizophrenia still shows the koping adaptive mechanisms of which respondents feel uncomfortable in doing treatments as well as respondents felt shame with neighbors around the House because of the stigma of being delivered by neighbors, so that sometimes make the family feel worried and depressed with their current circumstances. The existence of knowledge still lacking family owned in treating patients with schizophrenia caused the families feel intimidated with the stigma and waffle citizens around the House, besides the existence of the family fears if patients get out of the House and ngamuk endangers those around him. Because that's what families need psycho education so that families can reduce anxiety is experienced and can carry out its work in caring for their family members with schizophrenia.

Based on the gender of the respondent before the given psikoedukasi didapakan of the 19 respondents who-sex male majority has as much maladaptif koping mechanism 14 respondents 
(73.7\%) and in the female sex part great to have as many as 14 maladaptif koping mechanisms respondents $(63.6 \%)$. After being given psikoedukasi obtained data from the 19 respondents who are male-sex mostly have adaptive mechanisms koping by as much as 17 respondents (89.5\%) and on the gender of the majority of women have the mechanism of koping Adaptive as much as 17 respondents $(77.3 \%)$.

According to Siswanto (2012) one of the factors which affect the mechanisms of koping is factor from within IE age where the higher age koping individuals getting better, health and energy, belief system including kepercayan ekstensial (faith, religious belief, commitment) or life goals, past experience, knowledge or education level the higher the individual it is easy to search for information, sex women are more sensitive than men, the feeling of someone like self-esteem, control and proficiency, skill, problem solving.

The results of this research show that most respondents are men. On the male respondents were more mengedapankan how to find solutions to the problems faced by not using perasaaan to address permaslaahan so that gender men were more able to determine the strategy that should be koping used to overcome or create stress encountered in treating patients of schizophrenia lectures with the awarding of the psikoedukasi received so as to make the respondent had sufficient insight and respondents more capable in determining the right and koping mechanism suitable for them in create a stress that occurs at the time of patient care of schizophrenia.

\section{Identify the influence of psikoedukasi on stress management in improving self efficacy in treating family ODGJ (Schizophrenia) Public Health Center of Balowerti Kediri Regency}

Based on the results of research on the influence of psikoedukasi against self efficacy data obtained before the given psikoedukasi on schizophrenic family mostly have low self efficacy in treating sufferers as much as 29 respondents $(70.7 \%)$ and after given a psikoedukasi majority have high self efficacy as much as 32 respondents (78\%). Based on the results in table 4.9 shows that paired t test test results showed a psycho educational influence on self efficacy in treating patients with schizophrenia in Kediri Regency Balowerti Clinics, indicated by the value of the the significance of these two variables i.e. $0.050 .000<$ so that $\mathrm{H} 1$ is accepted means there is the influence of the psycho education towards self efficacy in families with schizophrenia in Kediri Regency Balowerti Clinics.

Research results Domínguez (2017) with the title of family education program for families (FTF) emotions and subjective knowledge about mental illness obtained results before (pretest) and after (posttest) FTF program. FTF causing a decrease in negative emotional attitudes and increase the understanding of the disorder, regardless of gender or age relative.

Schizophrenia is a psychotic disorder that is chronic or relapsing marked with examples of split (schism) between thoughts, emotions and behaviour of affected patients. The split in patients described by the presence of symptoms of the fundamental (or primary) specific, i.e. disorders characterized by impaired mind associations, particularly the looseness of the Association. Symptoms of other fundamental affective disorder, autism, and ambivalence. While the secondary symptoms are waham and hallucinations (Stuart, 2013). On the family caring for family members with the disorder the soul sometimes make families feel stressed and stress that it can affect their self efficacy. self efficacy are positive indicators of the self evaluation to conduct self-evaluation is useful to understand the self. Self efficacy is one aspect of knowledge about self or self kwoledge of the most influential in people's lives everyday due to self efficacy which belonged to influence individuals in determining the actions that will be undertaken to achieve a goal, including an estimate of the challenges facing (Bandura in research Yayan, 2013).

Psikoedukasi aims to help people with physical or mental health conditions certain to obtain the appropriate and accurate information about the condition. Psikoedukasi is not limited to individuals who suffer from illness or mental disorders but also can be given to another party such as a family with the goal of providing information that is important, explains the behavior that supports handling medical (drug consumption are appropriate dosage, regular checkups,) and provide support on the family by giving hope that problems experienced by one of its members can be tackled together (Anderson, in Walsh, 2010). 
The results showed that by administering the psycho education family capable of delivering on the change of beliefs that is owned by a family which before was given psikoedukasi about stress management many families which have self efficacy in merawata a family member with schizophrenia but after given appropriate psikoedukasi stages the many families who have high self efficacy. This is shown with a family feel calm in taking care of family members who suffered from schizophrenia and the family does not feel worried and anxious in doing treatments on the schizophrenic.

\section{Identify the influence of psikoedukasi on stress management in improving the mechanism of ODGJ in caring for families koping (Schizophrenia) Public Health Center of Balowerti Kediri Regency}

Based on the results of research on the influence of psikoedukasi against self efficacy data obtained before the given psikoedukasi family on schizophrenic the majority has the mechanism of Adaptive Mall koping in treating sufferers as much as 28 respondents $(68.3 \%)$ and after given a psikoedukasi majority have adaptive mechanisms koping by as much as 34 respondents (82.9\%). The results of this research show that the awarding of the psikoedukasi family in taking care of patients of schizophrenia affecting mechanism koping families become better than prior to the given psikoedukasi. Based on the results in table 4.9 shows that paired t test test results indicate the presence of the influence of the psycho education family in koping mechanism on treating patients with schizophrenia in Kediri Regency Balowerti Clinics, indicated by the value of the the significance of these two variables i.e. $0.050 .000<$ so that $\mathrm{H} 1$ is accepted means there is the influence of the psycho education family in koping mechanism against with schizophrenia in Kediri Regency Balowerti Clinics.

The results of this study in accordance with research of Tareq Abed Al Fattah Eteamah (2016) shows psychoedukasi in patients with mental disorders obtained the results of Executing the psycho educational program for families of patients with schizophrenia who often play an important role as a caregiver, promote recovery, and maintaining mental health care services, as well as implement a programme of psycho-education families at people in mental health treatment settings affect the treatment outcome mental in many dimensions.

According to the dictionary of psychology is the koping (behavior or action countermeasures) any deed, in which the individual performs the interaction with the surrounding environment. With the goal of completing something (Chaplin, 2009). Koping mechanism is every effort on the go for treatment of stress, including solving problems directly and the ego defence mechanisms in use to protect themselves (Gail. W. Stuart, 2013). Factors that determine which strategies are most numerous or frequently used really depends on the personality of the sesesorang, and the extent to which the level of stress from a condition or problem that had befallen him. An example of someone using the appropriate problem - solving focused coping in the face of the problems which he can be controlled. Such as, issues related to school or work. Otherwise would tend to use emotion focused coping strategies when faced with difficult problems which he controlled. The koping behavior focuses on the question of the function changes the relationship between the individual and the environment is in trouble by doing a direct action on the environment or the individual concerned (Nasir, 2011).

The results of this study indicate that by administering psikoedukasi about stress management can assist families in determining the right strategy koping to adapt to the form that is currently experienced, where families usually feel worry and anxiety so they can not adapt well, but after given psikoedukasi about family stress management is able to control the anxiety experienced so they can be more calm in doing treatments on family members who experience schizophrenia.

\section{CONCLUSION}

1. The families of schizophrenic in Kediri Regency Balowerti Clinics mostly have low self efficacy in treating sufferers as much as 29 respondents $(70.7 \%)$ before the given psycho education and after given psikoedukasi most have high self efficacy as much as 32 respondents (78\%). 
2. The families of schizophrenic the majority have adaptive mechanisms koping Mall in treating sufferers as much as 28 respondents $(68.3 \%)$ before psikoedukasi and after psikoedukasi has largely given the mechanism of koping Adaptive as much as 34 respondents (82.9\%).

3. There is a psycho educational influence on self efficacy in treating patients with schizophrenia in Kediri Regency Balowerti Clinics, indicated by the value of the significance of Test results at the $0.05<$ paired t test.

4. There is the influence of the psycho education family in koping mechanism on treating patients with schizophrenia in Kediri Regency Balowerti Clinics, indicated by the value of the significance of paired t test test results $<0.05$.

5. Psikoedukasi partially affect both variables self efficacy and mechanism of koping where indicated by the value of the wald on self efficacy of 11,154 with 0.001 and significance in koping mechanism of 13,186 wald with value the significance of 0.000 .

6. Psikoedukasi simultaneous affect both variables self efficacy and mechanism of koping where indicated by the value of the overall percentage of 76.8 which means psikoedukasi can affect both variables of $76.8 \%$.

\section{Suggestion}

1. For Public health center of Balowerti

Health officer of Public health center of Balowerti need to provide training, coaching and seminars to the poly soul so it can do the job with more appropriate in addition focused on patients but also can be focused on families such as the granting of therapeutic psikoedukasi so the care of patients with schizophrenia have become more precise. Additionally, on the health officer may perform nursing care of mainly the use of the communication strategy proper care in accordance with diganosa of nursing experienced by patients on either the family or the patient himself. Additionally, on the health officer may conduct surveillance of drug consumption in patients of schizophrenia patients so that more regular in taking medication and can help the healing process patients more effectively.

\section{For families}

Should the family more inmprovement information and knowledge about the care of schizophrenia patients by means of asking the officer or read a book about patient care of the soul so that it can enhance family knowledge and can be menignkatakn confidence and can reduce stress.

3. For the next Researcher

Further research should be done by direct observation or observation of self efficacy or mechanisms of koping family so that research results can be more optimally.

\section{REFERENCE}

Azizah, \& Ma'rifatul, L. (2011). Keperawatan Jiwa, Aplikasi Praktik Klinik. Yogyakarta: Graha Ilmu.

Bandura, A. (2009). Self Efficacy - The Exercise of Control. Fifth Printing. New York: W. H. Freeman \& Company.

Domínguez, T. (2017). Effects of Family-to-Family Psychoeducation Among Relatives of Patients With Severe Mental Disorders in Mexico City. Psychiatric Services Vo 4 No 68.

Donsu, \& Tine, J., D. (2016). Metodologi Penelitian. Yogyakarta: Pustaka Baru Press.

Eteamah, T., A., A. (2016). Literature Review: Application Of Psycho-Education For Families That Have Schizophrenia Patients. Middle East Journal Of Nursing Volume 10 Issue 3 September 2016. 
Ghozali, \& Imam. (2011). Aplikasi Analisis Multivariate. Badan Penerbit Universitas Diponegoro. Semarang.

Griffiths, P. (2016). An Introduction to English Semantics and Pragmatics. Edinburgh University Press Ltd.

Harnilawati. (2013). Konsep dan Proses Keperawatan Keluarga. Sulsel: Pustaka As Salam.

Hawari, D. (2011). Pendekatan Holistik pada Gangguan Jiwa Skizofrenia. Jakarta: FKUI.

Kaplan, M., D., \& Sadock, M., D. (2010). Buku Ajar Psikiatri Klinis. Edisi 2. Jakarta. EGC.

Keliat, B., A. (2011). Proses Keperawatan Kesehatan Jiwa. Edisi 5. Jakarta: EGC.

Kristyanti, \& Rosalina. (2009). Manajemen Stres Bagi Keluarga Penderita Skizofrenia. Jurnal Psikologi Universtitas Atmajaya Vol. 5 NO 132009.

Liyanovitasari. (2017). Pengaruh Terapi Suportif Kelompok Terhadap Beban Dan Mekanisme Koping Keluarga Dalam Merawat Pasien Skizofrenia. Nurseline journal Vol. 2 No. 2 Nopember 2017.

Nurbani. (2009). Pengaruh psikoedukasi keluarga terhadap masalah psikososial ansietas dan beban keluarga dalam merawat pasien stroke di RSUPN. Cipto Mangunkusumo. Jakarta.

Siswanto. (2012). Kesehatan Mental, Konsep, Cakupan Dan Perkembangannya. Yogyakarta: CV. Andi Offeset.

Sugiyono. (2016). Metode Penelitian Kuantitatif, Kualitatif Dan $R \&$ D. Cetakan ke-24. Bandung: Alfabeta.

Vacarolis, E., M. et al. (2013). Foundation of psychiatric mental health nursing a clinical approach. Edisi 5. Saunders Elseiver. St. Louis. Missouri.

Wijaya. (2014). Gambaran Psikoedukasi Terhadap Keluarga Penderita Skizofrenia. Psibernetika Vol. 7 No. 2 Oktober 2014.

Yayan. (2013). Membangun Motivasi Berprestasi: Pengembangan Self Efficacy dan Penerapannya dalam Dunia Pendidikan. Jurnal Pendidikan Motivasi Berprestasi.

Yosep, I. (2010). Keperawatan Jiwa. Cetakan Ketiga. (Edisi Revisi). Bandung: PT. Refika Aditama. 